\title{
Effects of 1-methylcyclopropene on postharvest quality of Roxo-de-Valinhos fresh ripe figs
}

\section{Efecto del 1-metilciclopropeno en la calidad poscosecha de frutos de higos maduros de la var. Roxo-de-Valinhos}
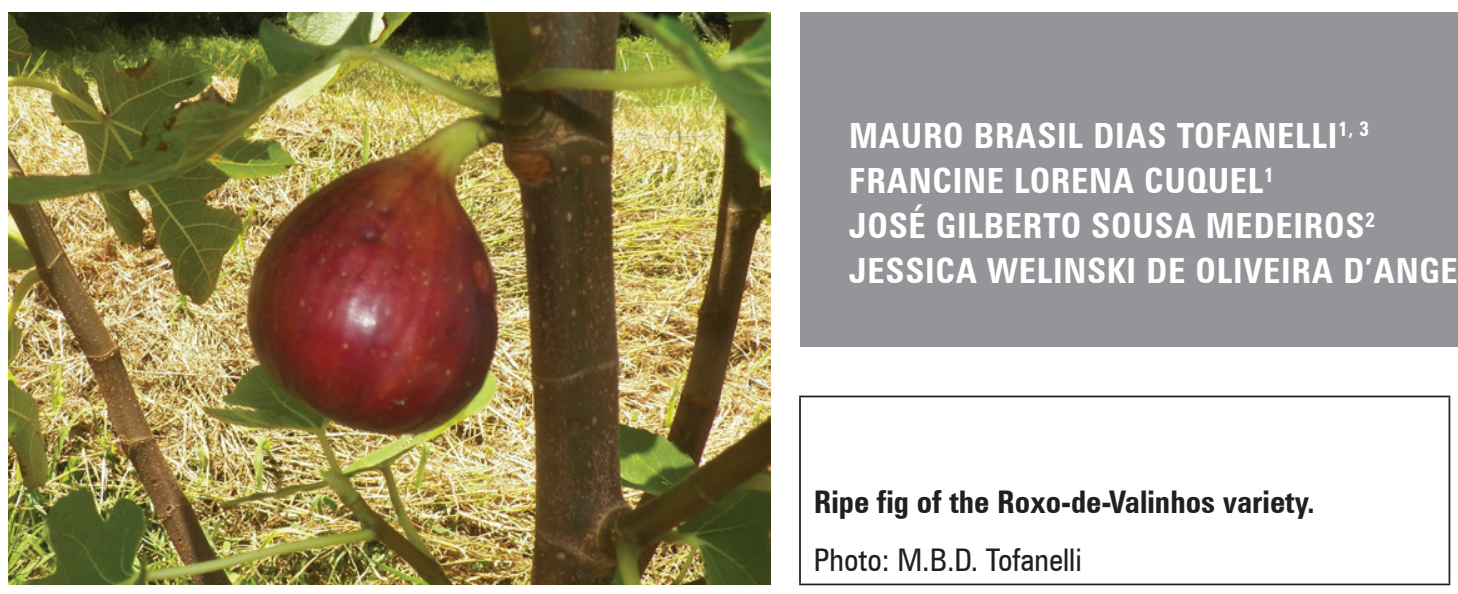

\section{ABSTRACT}

The fig is one of the most perishable fruits during the postharvest phase, which has prompted studies to evaluate the effects of substances applied on figs after harvest in order to extend their postharvest life. The aim of this work was to evaluate the effects of different concentrations of 1-methylcyclopropene (1-MCP) on the postharvest quality of Roxo de Valinhos figs. The research was conducted by applying 4 concentrations of 1-MCP $\left(0\right.$ - control, 5,10 , and $\left.20 \mu \mathrm{g} \mathrm{L}^{-1}\right)$ on figs, after which the fruits were evaluated at five different storage times $\left(0,4,8,12\right.$, and 16 days). The results showed that $20 \mu \mathrm{g} \mathrm{L}^{-1}$ of 1 -MCP provided the best fruit firmness at day 12 after harvest. The 1-MCP treatments did not improve the total amount of total soluble solids (TSS), but we observed higher amount of total solids from 12 to 16 days of storage. Higher acidity was observed in the figs without a 1-MCP treatment at 8 days of storage and with $20 \mu \mathrm{g} \mathrm{L}-1$ of 1-MCP after 12 days of storage. $1-\mathrm{MCP}$ did not affect fruit weight loss. The figs treated with 1-MCP showed promising and rising values of firmness, acidity, and TSS at the highest dose. The TSS concentration tended to increase at the higher doses. As a result, it could be interesting to assay this substance with applications with higher concentrations than those used in the present study.

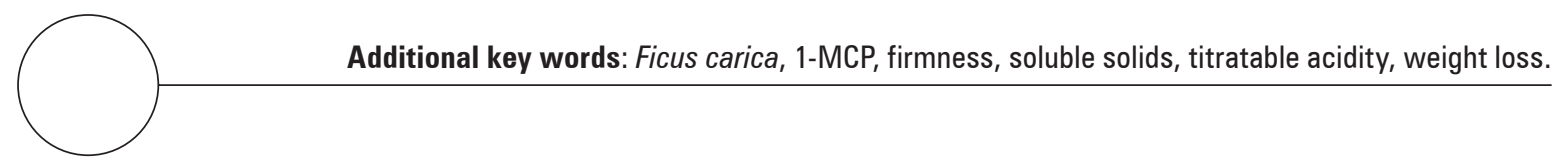

\footnotetext{
Universidade Federal do Paraná, Curitiba, PR (Brazil). ORCID Tofanelli, M.B.D.: 0000-0002-1831-3326; ORCID Cuquel, F.L.: 0000-0002-3026-2058; ORCID D’Angelo, J.W.d.O.: 0000-0001-7861-1600

2 Instituto Federal de Educação, Castanhal-PA (Brazil). ORCID Medeiros, J.G.S.: 0000-0002-3287-4189

3 Corresponding author. mbrasildt@ufpr.br
} 


\section{RESUMEN}

El higo es una de las frutas más perecederas en la poscosecha, lo cual ha promovido estudios para evaluar el efecto a aplicación de sustancias en el fruto después de la cosecha con el fin de conservar su calidad. El objetivo de este trabajo fue evaluar el efecto de diferentes concentraciones 1-metilciclopropeno (1-MCP) en la calidad de poscosecha del higo variedad Roxo-de-Valinhos. El experimento fue realizado con aplicaciones de cuatro concentraciones de 1-MCP (0 - testigo, 5, 10 y $\left.20 \mu \mathrm{g} \mathrm{L} \mathrm{L}^{-1}\right)$ en los frutos que fueran evaluados en cinco diferentes períodos de almacenamiento (0, 4, 8, 12 y 16 días). El tratamiento con 1-MCP no aumentó el contenido de sólidos solubles totales (SST), sin embargo se observó un considerable incremento en el período de 12 y 16 días de almacenamiento. La acidez elevada fue obtenida en los frutos no tratados con 1-MCP a los 8 días de almacenamiento y en los tratados con $20 \mu \mathrm{g} \mathrm{L} \mathrm{L}^{-1}$ de 1 -MCP a los 12 días de almacenamiento. El 1-MCP no influenció en la pérdida de peso de los frutos. Los higos tratados con las dosis de 1-MCP mostraron valores prometedores y crecientes de firmeza, acidez y SST. Las concentraciones de SST tendieron a aumentar a una dosis más alta, por lo que puede ser interesante probar esta sustancia aplicada en las concentraciones más altas que las utilizadas en este trabajo.

Palabras clave adicionales: Ficus carica, 1-MCP, firmeza, sólidos solubles, acidez titulable y pérdida de peso.

Received for publication: 23-08-2017 Accepted for publication: 30-01-2018

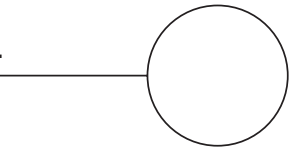

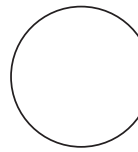

Figs are one of the most important commercial fruits around the world because of their nutritional compounds, taste, and traditional production. Figs are commercially grown in Brazil and 28,044 $t$ of the fruit were produced in 2014, mainly in the southeastern and southern Brazilian regions (IBGE, 2016), for fresh fruit consumption or for industries. In Brazil, the fig for fresh consumption - called "mature fig" is harvested at the maturation stage and the fig for processing - called "green fig" - is harvested before ripening.

However, certain concerns about fig tree (Ficus carica L.) plantations have prompted studies to find solutions, such as the need to address the perishable nature of the fresh fig, which rapidly decreases the quality of the fruit after harves, because it is subject to rapid physiological breakdown. This characteristic affects the efficiency of the commercialization and exportation of the fruit around the world (Gözlekçi et al., 2008; Paula et al., 2007; Sharma and Singh, 2013). The postharvest life of the fresh fig fruit is normally 7-10 d even when it is stored under low temperatures (Ozkaya et al., 2014).

Some studies have been conducted to investigate the effects of substances applied on figs to improve its postharvest conservation, such as calcium chloride, fungicides, sodium hypochlorite, and 1-methylcyclopropene (1-MCP) (Gözlekçi et al., 2008; Irfan, 2013; Paula et al., 2007; Watkins, 2008). 1-MCP is an unsaturated cyclic olefin that acts as a competitive ethylene antagonist, i.e. it blocks ethylene receptors and can be used to control ethylene production, respiration rate, and softening and extends the shelf-life of a wide range of fruits (Freiman et al., 2012; Sozzi et al., 2005; Terra et al., 2014; Watkins, 2008). However, 1-MCP applications on fruits may not always have similar results on the postharvest quality since its effect has been shown to vary according to the climacteric fruit species, cultivar, maturation and ripening stages of the fruit, and 1-MCP application forms (Freiman et al., 2012; Sozzi et al., 2005; Watkins, 2006; Zhang et al., 2017).

There are few reports on the postharvest behavior of figs treated with 1-MCP. Gözlekçi et al. (2008) showed that $10 \mu \mathrm{g} \mathrm{L} \mathrm{L}^{-1}$ of 1 -MCP slowed the softening of Bardakci figs and retained fruit firmness during a 15-day storage period in styrofoam trays wrapped with commercial cling film at $0^{\circ} \mathrm{C}$ and 90 $92 \%$ relative humidity $(\mathrm{RH})$. D'Aquino et al. (2003) treated Bianca figs with $400 \mu \mathrm{g} \mathrm{L}-1$ of $1-\mathrm{MCP}$ at $20^{\circ} \mathrm{C}$ for $24 \mathrm{~h}$ and concluded that 1-MCP treatment of the figs and storage for $7 \mathrm{~d}$ at $15^{\circ} \mathrm{C}$ may improve their storability. 
To the best of our knowledge, very few studies have reported on the postharvest management of fresh fig cultivars and even fewer have considered postharvest behavior after 1-MCP-treatment. The aim of this work was to evaluate the effects of 1-MCP applications on the postharvest quality of Roxo-de-Valinhos figs.

\section{MATERIALS AND METHODS}

\section{Study area}

Figs were harvested from plants grown in a orchard located in Pinhais County, Paraná State, Brazil $\left(25^{\circ} 26^{\prime}\right.$ $\mathrm{S}$ and 49 $16^{\prime}$ W; $947 \mathrm{~m}$ a.s.1.), with a Cfb Koeppen climate, average temperature of $24^{\circ} \mathrm{C}$ maximum and $11^{\circ} \mathrm{C}$ minimum, and annual rainfall average of 1,500 $\mathrm{mm}$. After harvest, the figs were immediately transported to the Postharvest Laboratory for the experiment procedures.

\section{Plant material}

The fig trees were 5-year-old Roxo-de-Valinhos cultivars. The plants were cultivated in an organic system, subjected to annual drastic pruning, and spaced at $1 \times 3 \mathrm{~m}$. Annual fertilization was done using cattle manure at $60 \mathrm{~L}$ per plant, three times every $60 \mathrm{~d}$ starting from August. Diseases were controlled by spraying with lime sulfur after pruning and a Bordeaux mixture during the vegetative and production stages of the fig trees. To control weeds, mechanical weeding in the crop rows and mowing were used, integrated with black oat (Avena strigosa L.), planted in July once a year. The figs were hand-harvested on 12 April, 2014, collecting fruits that showed changing skin color, green to reddish, at stage 5 (Freiman et al., 2012).

\section{Experiment description}

Harvested figs were separated into lots at the Postharvest Laboratory so that each lot had 10 figs, enabling storage for $0,4,8,12$, and $16 \mathrm{~d}$, and they were placed in a paper box. Thereafter, the figs were ready to be treated with 1-MCP.

\section{Postharvest 1-MCP treatments}

1-MCP was used in the form of SmartFresh ${ }^{\circledR}$ powder $(0.14 \%$ active ingredient $)$. The figs were treated with the 1-MCP solution of the corresponding concentration. The 1-MCP doses were measured with a precision balance, and then they were dissolved in distillated water to obtain each deluded solution. The 1-MCP concentrations were 5, 10 , and $20 \mu \mathrm{g} \mathrm{L}{ }^{-1}$. The untreated control $\left(0 \mu \mathrm{g} \mathrm{L}^{-1}\right)$ only used distilled water.

The treatments were applied in plastic gallon containers $(70 \mathrm{~L})$, which already contained figs indoor. The 1-MCP solutions were injected into the containers using plastic syringes, which were immediately sealed in order to preserve the vapor of the solutions. Thus, the 1-MCP powder was introduced into a syringe, supplemented with water until a specific volume for the required concentration, and immediately applied to the containers. The duration of treatments was 24 hours.

\section{Storage conditions}

Following the 1-MCP treatment, the figs were placed in paper boxes capable of storing 8 fruits and stored at $4 \pm 1^{\circ} \mathrm{C}$ and $90-95 \% \mathrm{RH}$ for $16 \mathrm{~d}$. For each treatment, three replicates of each sample with 10 figs per replicate were used for the physical and chemical quality analyses; two figs were analyzed immediately post 1 -MCP-treatment and the other 8 figs were stored. There were five storage periods $(0,4,8,12$, and $16 \mathrm{~d}$ ) in order to evaluate the postharvest quality conservation.

\section{Physical and chemical qualities}

For measuring the firmness, total soluble solids (TSS) concentration, total titratable acidity (TTA), and weight loss (Instituto Adolfo Lutz, 2008; Leonel and Tecchio, 2008), samples were periodically withdrawn from the refrigerator and two figs per replicate were used for the analyses every $4 \mathrm{~d}$. The peeled-fruit firmness was determined using a manual penetrometer (PTR-100) with a 7.9-mm-diameter tip and expressed in pounds (1b); the data were multiplied by 4.44 to be expressed in Newton $(\mathrm{N})$. The stored figs were taken from the refrigerator to put them on the penetrometer so that they could be analyzed on the equatorial part of the fruit.

The fruit juice was extracted using a centrifuge to measure the TSS and TTA. The TSS content was measured with a handheld refractometer using a drop of juice and expressed as ${ }^{\circ}$ Brix. The TTA, expressed as \% citric acid, was measured using $100 \mathrm{~mL}$ of the solution (10 $\mathrm{mL}$ of juice $+90 \mathrm{~mL}$ distilled water) that 
were immediately titrated with $0.1 \mathrm{~N} \mathrm{NaOH}$ using three drops of phenolphthalein as an indicator.

The weight loss of the stored figs was analyzed using the relative weight variation (\%) of two figs per replicate. These figs also represented a storage period of $16 \mathrm{~d}$. The fruits were weighed at harvest and at every storage period, and the weight loss was also determined. The fruit weights were determined using an electronic balance.

\section{Experiment design}

The experiment was carried out as a completely randomized factorial design with three replicates and two figs per replicate. Thus, a $2^{2}$ factorial arrangement was used: (1) 1-MCP concentration with four levels $\left(0,5,10\right.$, and $\left.20 \mu \mathrm{g} \mathrm{L}^{-1}\right)$ and (2) storage period at five levels $(0,4,8,12$, and $16 \mathrm{~d})$.

\section{Statistical analysis}

The data were submitted to analysis of variance (ANOVA) using the Sisvar Statistical Program, version 5.3 (Ferreira, 2010). When treatment effects were detected with ANOVA, multiple comparisons for the mean were done using the Tukey test at a 5\% probability level. Regression analysis was used when a qualitative parameter expressed significant effect.

\section{RESULTS AND DISCUSSION}

\section{Firmness}

The 1-MCP treatments showed no influence on the firmness of the fig fruits. However, there were significant effects of the 1-MCP treatments on the fig firmness over the different storage periods (Tab. 1). The $20 \mu \mathrm{g} \mathrm{L}^{-1} 1$-MCP treatment showed the best firmness result after $12 \mathrm{~d}$ in storage $(26,8 \mathrm{~N})$ although the 5 and $10 \mu \mathrm{g} \mathrm{L}^{-1}$ of 1-MCP showed similar results to $20 \mu \mathrm{g} \mathrm{L}^{-1}$ of 1 -MCP after 8 and 16 storage days.

The apparent increase in fruit firmness observed during storage could be related to the fresh weight loss. Fruit shriveling may hamper penetration of a penetrometer tip into figs because weight loss causes laxity and elasticity. Pectins act as a cementing material and are found mainly in the cell wall, being responsible for fruit firmness (Álvarez-Herrera et al., 2016). Thus, the 1-MCP promoted less pectin solubilization in the treated figs, which probably caused delay of the ethylene effect on the pectinase enzymes present in the cell wall; consequently, fuit firmness was promoted (Blum and Ayub, 2009; Oliveira et al., 2005; Terra et al., 2014).

Ribeiro et al. (2012) observed that the resistance grape peels increased when they shriveled in their final ripening stage. Brunini et al. (2011) also reported that weight loss in pitaya fruit resulted in peel laxity, causing difficulty for penetrometer tip penetration. Brackmann and Saquet (1995) and Jeronimo et al. (2007) also studied the firmness of persimmons and mangos, respectively, and suggested that fruit firmness may increase because of fruit shriveling.

\section{Total soluble solids}

The results of the present study showed that the 1-MCP treatment influenced the TSS concentration. The ${ }^{\circ}$ Brix degree reduced with increasing 1-MCP doses, until $12.2 \mu \mathrm{g} \mathrm{L}^{-1}$ (Fig. 1). According to Blum and Ayub (2009), 1-MCP exhibits ethylene biosynthesis and consequently affects the rate of starch

Table 1. Effects of the 1-MCP treatments and storage periods on the firmness of ripe figs.

\begin{tabular}{|c|c|c|c|c|c|}
\hline \multicolumn{5}{|c|}{ Storage period (d) } \\
\hline 1 -MCP & \multicolumn{5}{|c|}{ Firmness (N) } \\
\hline$\left(\mu \mathrm{g} \mathrm{L}^{-1}\right)$ & 0 & 4 & 8 & 12 & 16 \\
\hline 0 & $16.7 \mathrm{aAB}$ & $18.6 \mathrm{abAB}$ & $21.0 \mathrm{aA}$ & $6.8 \mathrm{bB}$ & $7.4 \mathrm{aB}$ \\
\hline 5 & $13.0 \mathrm{aAB}$ & $22.4 \mathrm{aA}$ & $19.9 \mathrm{aAB}$ & $21.2 \mathrm{aAB}$ & $9.1 \mathrm{aB}$ \\
\hline 10 & $16.0 \mathrm{aA}$ & $21.9 \mathrm{aA}$ & $22.5 \mathrm{aA}$ & $15.9 \mathrm{abA}$ & $12.3 \mathrm{aA}$ \\
\hline 20 & $12.0 \mathrm{aB}$ & $9.7 \mathrm{bB}$ & $21.1 \mathrm{aAB}$ & $26.8 \mathrm{aA}$ & $15.5 \mathrm{aAB}$ \\
\hline
\end{tabular}

Values followed by the same uppercase letter in a row and lowercase letter in a column are not significantly different from each other according to the Tukey test $(P \leq 0.05)$. 
degradation, which is responsible for increasing the concentration of TSS. In the present study, 1-MCP likely exhibited ethylene production mainly from the dose of $12.2 \mu \mathrm{g} \mathrm{L} \mathrm{L}^{-1}$. Sisler et al. (1996) showed that exposure to $1-\mathrm{MCP}$ for $6 \mathrm{~h}$ at $500 \mathrm{~mL} \mathrm{~L}^{-1}$ made bananas insensitive to ethylene for 12 days and carnations for $24 \mathrm{~h}$, but mature-green tomatoes became insensitive to ethylene for 8 days at $5000 \mathrm{~mL} \mathrm{~L}^{-1}$ of 1 -MCP. Freiman et al. (2012) showed that preharvest untreated and 1-MCP-treated figs showed different concentrations of SS, implying that the level of SS in untreated figs increased significantly (about 22\%), but not in treated figs.

The storage periods also demonstrated a significant effect on the SS concentration. The SS levels increased as the 1-MCP doses increased (Fig. 2). Blum and Ayub (2009) also studied the effect of 1-MCP applied on persimmon and observed that SS levels increased for

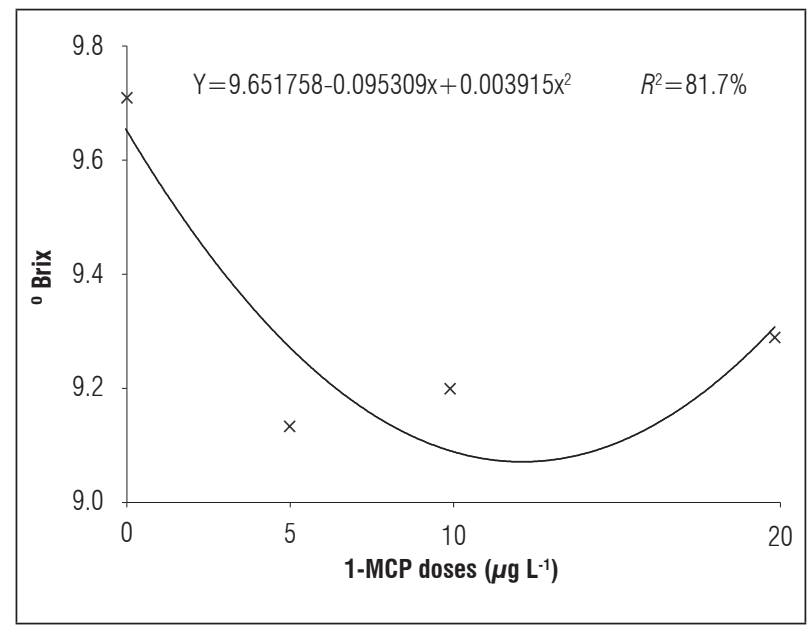

Figure 1. Effects of the 1-MCP treatments on the total soluble solids ( ${ }^{\circ} \mathrm{Brix}$ ) in the ripe figs.
$20 \mathrm{~d}$. The increase of TSS in fruits can be explained by the hydrolysis of various polysaccharides, such as starch, pectins, and other oligosaccharides in the cell wall, which, when solubilized in the aqueous phase, become part of the cellular juice, as well as by starch accumulation during fruit maturation, which degrades into sugars through the enzymatic action of $\alpha$-amylase, $\beta$-amylase, and starch phosphorylase, increasing TSS concentration (Deaquiz et al., 2014). There was no interaction effect of the levels of 1-MCP treatment and storage time.

\section{Total titratable acidity}

The acidity of the figs was affected by the interaction between the 1-MCP treatment and storage time (Tab. 2). Higher acidity was observed in the 1-MCP-untreated figs stored for $8 \mathrm{~d}$ and in the figs treated with $20 \mu \mathrm{g} \mathrm{L}^{-1}$ of 1 -MCP stored for $12 \mathrm{~d}$. In general, little

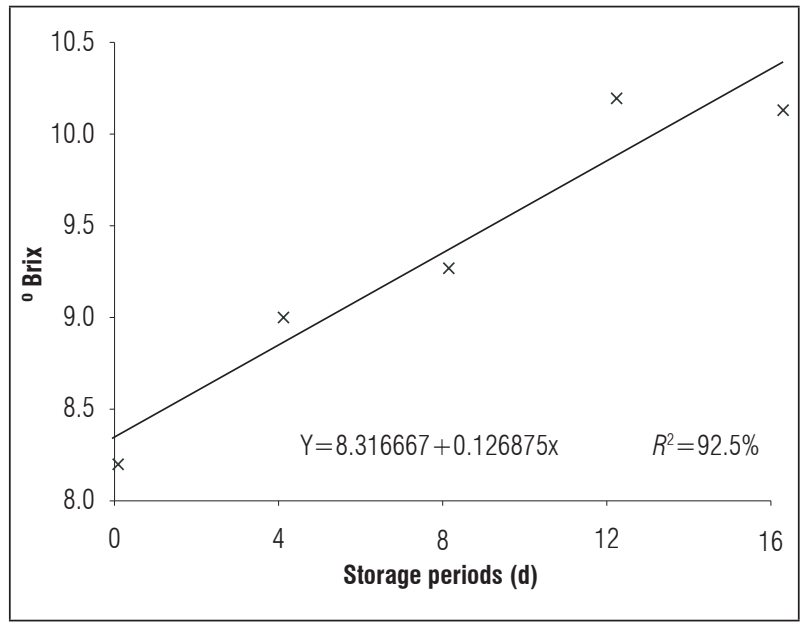

Figure 2. Concentration of total soluble solids ( ${ }^{\circ}$ Brix) in the ripe figs after different storage periods after harvest.

Table 2. Effects of the 1-MCP treatments and storage periods on the total titratable acidity (TTA) of ripe figs.

\begin{tabular}{|c|c|c|c|c|c|}
\hline \multicolumn{5}{|c|}{ Total titratable acidity (\%) } \\
\hline 1 -MCP & \multicolumn{5}{|c|}{ Storage period (d) } \\
\hline$\left(\mu \mathrm{g} \mathrm{L}^{-1}\right)$ & 0 & 4 & 8 & 12 & 16 \\
\hline 0 & $0.17 \mathrm{aC}$ & $0.21 \mathrm{abB}$ & $0.28 \mathrm{aA}$ & $0.17 \mathrm{bC}$ & $0.20 \mathrm{aB}$ \\
\hline 5 & $0.16 \mathrm{aB}$ & $0.21 \mathrm{aA}$ & $0.21 \mathrm{bA}$ & $0.20 \mathrm{aA}$ & $0.19 \mathrm{abAB}$ \\
\hline 10 & $0.16 \mathrm{aB}$ & $0.22 \mathrm{aA}$ & $0.21 \mathrm{bA}$ & $0.18 \mathrm{abB}$ & $0.17 \mathrm{bB}$ \\
\hline 20 & $0.16 \mathrm{aC}$ & $0.19 \mathrm{bB}$ & $0.22 \mathrm{bA}$ & $0.24 \mathrm{aA}$ & $0.19 \mathrm{abAB}$ \\
\hline
\end{tabular}

Values followed by the same uppercase letter in a row and lowercase letter in a column are not significantly different from each other according to the Tukey test $(P \leq 0.05)$. 
increase in acidity was observed during the initial of storage period and, thereafter, it decreased during the final of storage period for all treatments, indicating an apparent acidity establishment. Candan et al. (2011) treated plums with 1-MCP and observed that Royal Zee cultivar fruits showed similar values of TTA in both control and in treated fruits. According to the authors, maintained TTA levels might affect a fruit's final sensory quality. Paula et al. (2007) also observed increased acidity initially, and, later, decreasing acidity in figs treated with fungicide and calcium chloride, which they attributed to fruit quality improvement through mainly lower weight loss and higher firmness.

\section{Weight loss}

As expected, the fruit weight loss was very prominent as the storage period was prolonged (Fig. 3). Paula et al. (2007) also showed similar results. The 1-MCP did not significantly influence the fruit weight loss; neither did the interaction between storage time and 1-MCP. However, Ozkaya et al. (2014) showed that a 1-MCP treatment inhibited ethylene evolution and decreased fruit respiration in 'Bursa Siyahi' figs, which likely resulted in less weight loss in the 1-MCP treated fruit. They highlighted the fact that weight loss is one of the most important causes of fruit quality deterioration.

Figs are highly perishable fruits, in which events such as respiration, dehydration, and degradation happen very fast (Gözlekçi et al., 2008; Ozkaya et

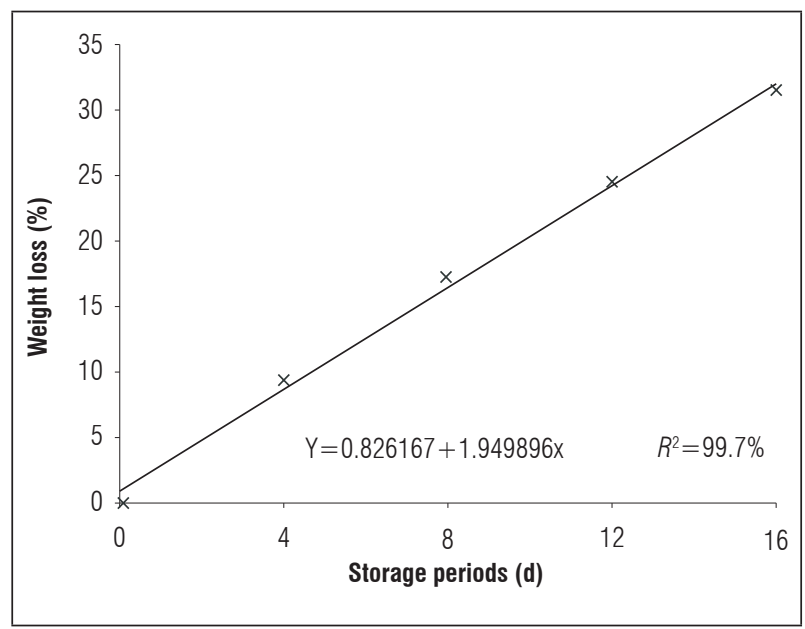

Figure 3. Weight loss in the ripe figs after different storage periods after harvest. al., 2014). In addition to this, figs are morphologically interesting fruits that have a particular structure called ostiole that increases water loss through evaporation by exudation of a syrupy liquid through this orifice (Campos, 1994; D'Aquino et al., 2003; Freiman et al., 2012). It is possible that the ostiole is one factor masking 1-MCP treatments of fig. For this reason, it may be interesting to investigate the effects of higher 1-MCP-doses and longer treatment periods combined with other techniques, such as bagging or wrapping, on the conservation and quality of Roxo-de-Valinhos figs.

\section{CONCLUSION}

The 1-MCP treatment improved the quality (firmness and acidity) of ripe Roxo-de-Valinhos figs during storage. Testing doses higher than $20 \mu \mathrm{g} \mathrm{L}^{-1}$ of 1 -MCP would be interesting because it was observed that the soluble solids tended to increase from 10 to $20 \mu \mathrm{g} \mathrm{L}^{-1}$. On the order hand, the 1-MCP treatment was not able to reduce the high weight loss in the Roxo-de-Valinhos fresh ripe figs.

Conflict of interests: the manuscript was prepared and reviewed with the participation of the authors, who declare that there exists no conflict of interest that puts in risk the validity of the presented results.

\section{BIBLIOGRAPHIC REFERENCES}

Álvarez-Herrera, J.G., Y.A. Deaquiz, and A.O. Herrera. 2016. Effect of different 1-methylcyclopropene doses on the postharvest period of pitahaya fruits (Selenicereus megalanthus Haw.). Rev. Fac. Nac. Agron. Medellín 69(2), 7975-7983. Doi: 10.15446/rfna.v69n2.59142

Blum, J. and R.A. Ayub. 2009. Amadurecimento do caqui Quioto tratado com 1-Metilciclopropeno e armazenado à temperatura de $20 \pm 4^{\circ} \mathrm{C}$. Ceres 56(2), 119-123.

Brackmann, A. and A.A. Saquet. 1995. Efeito da temperatura e condições de atmosfera controlada sobre a conservação de caqui (Diospyrus kaki, L.). Ciênc. Rural 25(3), 375-378. Doi: 10.1590/S0103-84781995000300007

Brunini, M.A. and S.S. Cardoso. 2011. Qualidade de pitaias de polpa branca armazenadas em diferentes temperaturas. Rev. Caatinga 24(30), 78-84.

Campos, A.D. 1994. Aspectos pós-colheita do figo. Informe Agropecuário 17, 19-21.

Candan, A.P., J.Graell, and C. Larrigaudière. 2011. Postharvest quality and chilling injury of plums: benefits of 
1-methylcyclopropene. Span. J. Agric. Res. 9(2), 554564. Doi: 10.5424/sjar/20110902-259-10

D'Aquino, S., A. Palma, A. Dore, and M. Agabbio. 2003. Non conventional treatments to reduce figs decay. Acta Hortic. 604, 817-821. Doi: 10.17660/ ActaHortic.2003.604.105

Deaquiz, Y.A., J. Álvarez-Herrera, and G. Fischer. 2014. Ethylene and 1-MCP affects the postharvest behavior of yellow pitahaya fruits (Selenicereus megalanthus Haw.). Agron. Colomb. 32(1), 44-51. Doi: 10.15446/ agron.colomb.v32n1.41950

Ferreira, D.F. 2010. Sisvar. Sistema de análise de variância. Versão 5.3. UFLA, Lavras-MG, Brazil.

Freiman, Z.E., V. Rodov, Z. Yablovitz, B. Horev, and M.A. Flaishman. 2012. Preharvest application of 1-methylcyclopropene inhibits ripening and improves keeping quality of 'Brown Turkey' figs (Ficus carica L.). Sci. Hortic. 138, 266-272. Doi: 10.1016/j.scienta.2012.01.007

Gözlekçi, S., M. Erkan, I. Karaşahin, and G. Şahin. 2008. Effect of 1-methylcyclopropene (1-MCP) on fig (Ficus carica 'Bardakci') storage. Acta Hortic. 798, 325-330. Doi: 10.17660/ActaHortic.2008.798.47

Instituto Adolfo Lutz. 2008. Métodos físicos e químicos para análise de alimentos. Instituto Adolfo Lutz, São Paulo-SP, Brazil.

Instituto Brasileiro de Geografia e Estatística. Sistema. IBGE. 2016. Sistema IBGE de Recuperação Automática - Sidra. In: http://www.sidra.ibge.gov.br; consulted: July, 2016.

Irfan, P.K., V. Vanjakshi, M.K. Prakash, R. Ravi, and V.B. Kudachikar. 2013. Calcium chloride extends the keeping quality of fig fruit (Ficus carica L.) during storage and shelf-life. Postharvest Biol. Technol. 82, 70-75. Doi: 10.1016/j.postharvbio.2013.02.008

Jeronimo, E.M., M.A. Brunini, M.C. de Arruda, J.C.S. Cruz, I.H. Fischer, and G.J. de C. Gava. 2007. Conservação pós-colheita de mangas 'Tommy Atkins' armazenadas sob atmosfera modificada. Semin. Ciênc. Agrár. 28(3), 417-426. Doi: 10.5433/1679-0359.2007v28n3p417

Leonel, S. and M.A. Tecchio. 2008. Produção da figueira submetida a diferentes épocas de poda e irrigação. Rev. Bras. Frutic. 30(4), 1015-1021. Doi: 10.1590/ S0100-29452008000400029

Oliveira, F.E. da R., C.M.P. de Abreu, S.A. Asmar, A.D. Corrêa, and C.D. dos. Santos. 2005. Firmeza de pêssegos 'diamante' tratados com 1-MCP. Rev. Bras. Frutic. 27(3), 366-368. Doi: 10.1590/S0100-29452005000300007

Ozkaya, O., S. Çömlekçioglu, and H. Demircioglu. 2014. Assessment of the potential of 1-methylcyclopropene treatments to maintain fruit quality of the common fig. Not. Bot. Horti. Agrobo. 42(2), 516. Doi:10.1583/ nbha4229647

Paula, L.A. de, J. dos S. Isepon, and L. de S. Corrêa. 2007. Qualidade pós-colheita de figos do cv Roxo-de-Valinhos com aplicação de cloreto de cálcio e fungicidas. Acta Sci. Agron. 29(1), 41-46. Doi: 10.4025/actasciagron.v29i1.64

Ribeiro, T.P., M.A.C. de Lima, and R.E. Alves. 2012. Maturação e qualidade de uvas para suco em condições tropicais, nos primeiros ciclos de produção. Pesqui. Agropecu. Bras. 47(8), 1057-1065. Doi: 10.1590/S0100-204X2012000800005

Sharma, S.P. and P. Singh. 2013. Extending the post-harvest life of unrefrigerated fig (Ficus carica L.) fruits by modified packaging system in India. Progress. Res. 8, 89-94.

Sisler, E.C., M. Serek, and E. Dupille. 1996. Comparison of cyclopropene, 1-methylcyclopropene, and 3,3-dimethylcyclopropene as ethylene antagonists in plants. Plant Growth Regul. 18, 169-174. Doi: 10.1007/ BF00024378

Sozzi, G.O., M. A. Abraján-Villaseñor, G.D. Trinchero, and A.A. Fraschina. 2005. Postharvest response of 'Brown Turkey' figs (Ficus carica L.) to the inhibition of ethylene perception. J. Sci. Food Agric. 85, 2503-2508. Doi: 10.1002/jsfa.2296

Terra, F.D.A.M., F. K. Edagi, F.F.C.Sasaki, M.E. Frassetto Filho, M. M. da Silva, B. Giro, N.D. Berno, and R.A. Kluge. 2014. Aplicação do 1-metilciclopropeno e sua influência no processo de remoção da adstringência com etanol em caqui ‘Giombo' refrigerado. Ciênc. Rural 44(2), 210-216. Doi: 10.1590/S0103-84782014000200003

Watkins, C.B. 2008. Overview of 1-methylcyclopropene trials and uses for edible horticultural crops. HortScience 43(1), 86-94.

Zhang, J., D. Cheng, B. Wang; I. Khan, and Y. Ni. 2017. Ethylene control technologies in extending postharvest shelf life of climacteric fruit. J. Agric. Food Chem. 65(34), 7308-7319. Doi: 10.1021/acs.jafc.7b02616 